\title{
VERBALIZATION OF THE HEALING PROPERTIES OF THE DENOTATA IN THE NAMES OF MEDICINAL PLANTS: THE EXTRALINGUISTIC ASPECT OF MONOLINGUAL EDUCATION (BY THE MATERIAL OF GERMAN)
}

\author{
Oksana G. Kuptcova ${ }^{1}$, Anna L. Kolyago ${ }^{2 \star}$, \\ Alla A. Fokina ${ }^{3}$, Elena L. Petrova ${ }^{4}$, Galina L. Sokolova ${ }^{5}$ \\ ${ }^{1}$ As. Prof., Interregional Open Social Institute, Mari State University, RUSSIA, \\ kuptcovaOG@yandex.ru \\ ${ }^{2}$ As. Prof., Mari State University, RUSSIA, kolyago@yandex.ru \\ ${ }^{3}$ As. Prof., Mari State University, RUSSIA, allafokina70@mail.ru \\ ${ }^{4}$ As. Prof., Mari State University, RUSSIA, jandar78@mail.ru \\ ${ }^{5}$ As. Prof., Mari State University, RUSSIA, askgalinasokol@mail.ru \\ ${ }^{*}$ Corresponding author
}

\begin{abstract}
Modern linguistics has extensive experience in mono-and multilingual comparative study and description of the names of medicinal plants. Medicinal plants have been an excellent treatment and prevention of diseases. To identify the right plant among many similar ones, people gave them easy-to-remember names based on the appearance of the plant, the period of its flowering or the place of growth. But due to the fact that the main field of application of medicinal plants is healing, herbalists and healers often gave plants names associated with the cause of the disease, the purpose of treatment, the method of application of the medicinal plant. If the plant helped with skin diseases, then the lexeme clean was used, if it was necessary to stop the bleeding, then the phytonym could include the lexeme blood, a cut.

The extralinguistic aspect of monolingual education implies a description of the phytonymic vocabulary in the German language, taking into account the ethnolinguistic factor of the nomination. The paper analyzes and systematizes the German names of the most common medicinal plants and their corresponding scientific and dialect phytonyms. Phytonyms are differentiated and described on the basis of motivational features common to each lexico-semantic group. The purpose of this study is to analyze the German dialect and literary names of herbaceous medicinal plants from the point of view of displaying the medicinal properties of the denotata. The task of the study is to determine the etymology of these pharmacophytonyms, as well as the word-formation motivation of one-word names (and components of multi-word names); to analyze the structure of names and identify ways of nomination. The German names of medicinal plants collected and published in the Short Quadrilingual Dictionary of Phytonyms (Rubtcova, 2015) served as the material for the study.
\end{abstract}

Keywords: phytonym, motivema, the German language, language education, medicinal plants, nomination, magic properties, traditional medicine.

\section{INTRODUCTION}

Folk medicine goes way far back. People have transmitted knowledge about the healing effects of medicinal plants across generations for many centuries. The knowledge of plants' healing properties gave people the 
opportunity to use many of them as the main medicine. The centuries-old folk experience of healing has been the source of modern medical knowledge. Even today, during the development of highly qualified medical care, people resort to homeopathy, to treatment with medicinal plants. Therefore, phytotherapy is still one of the leading methods of treating diseases of various etiologies.

This research continues the series of articles devoted to the study of language education in the German language (Bogdanova, Kolyago, Fokina, Sokolova, Yandakova, 2017), (Sokolova, Kolyago, Fokina, Rychkov, Bogdanova, Trubyanova, Yandakova, 2017)

\section{OPINION AND DISCUSSION}

Functional identities within the designated lexico-semantic group help to systematize the selected phytonyms into subgroups with a common motivating feature.

1. Phytonyms revealing the universality of plant use. Some plants are highly specialized and used only for certain diseases, while others are so universal that they are able to treat diseases of various etiologies, relieve malaise and give vigor and strength to a person. The generic name of marshmallow Althaea could come from Greek. althainein 'to heal, to treat', healing properties of the reality are reflected in the German language - Apotheker-Eibisch (German. der Apotheker 'apothecary, pharmacist'), Hilfwurz (German. helfen 'to help'), Heilwurzel (German. heilen 'to cure, to heal'). The Germans respectfully call elecampane as Edelwurz (German edel 'honorable, noble', die Wurz archaic. dialect. 'root') or Galantkraut (German gallant 'gallant, courteous'), perhaps it is due to plant popularity, which helps in the treatment of many human or animal diseases.

2. Phytonyms revealing hemostatic properties of plant. The names of plants do not always contain lexemes that directly indicate wound-healing and hemostatic properties of reality. Very often, the process of plant nomination proceeds indirectly. Lexemes can be represented in phytonyms embodying the process and result of household or agricultural activities, as a result of which situations arise when it is necessary to apply a particular plant as a hemostatic remedy. Plant ability to stop uterine bleeding is evidenced by elements of gender identity. Yarrow, as a hemostatic, is used for various bleeding (pulmonary, intestinal, nasal, uterine) and cuts: Jungfraukraut (German jungfraulich) 'virgin, girlish') (during uterine bleedings and the whites), Wundheitkraut (German. die Wundheit 'wound (traumatic) injury'; das Kraut 'grass'), Blutstillkraut (German. die Blutstillung 'stopping bleeding'). These amazing properties of yarrow are recorded in the Botanical Dictionary by N. Annenkov as follows: yarrow "is taken for hemorrhoidal and uterine bleeding, for pain during menstruation, for mucous whites, girlish infirmity. In Russian folk medicine, it is used to stop bleeding in a cut, for the appearance of mother's milk" (Annenkov, 1878). In monolingual reference books of medicinal plants, you can find a similar description of yarrow use: "Schafgarbe ist aber auch ein großes Frauenmittel bei Menstruationsstörungen und Ausfluss. Der frisch gepresste Schafgarbensaft gilt als hervorragendes Blutreinigungsmittel" (Wendelberger, 2013) "Yarrow is also an indispensable remedy for women with menstrual disorders and whites. Freshly squeezed juice is considered an excellent remedy for stopping bleeding'. Hypericum: Blutkraut (German das Blut 'blood'), Wundkraut (German die Wunde 'wound; wound'); snakeweed: Blutkraut, Blutkrautknöterich (German das Blut 'blood'); burnet: Blutwurzel, Blutströpfchen (German das Blut 'blood') are plants with wound-healing and hemostatic properties. Knot grass is contained in so-called blood-purifying teas, because it helps to regulate metabolism: Blutgarbe (German: das Blut 'blood'; die Garbe botanic. 'yarrow').

3. Phytonyms defining the purpose of treatment. Phytonyms that identify the purpose of treatment can be based on the desired result, which was sought to obtain during the prevention of disease or treatment process itself. The use of fresh aloe leaves as a wound healing agent for skin diseases (burns, boils, eczema, etc.) is reflected in the German pharmacophytonym Brandbaum (German: der Brand 'burn'; der Baum 'tree'). Decoction of wormwood -Wiegekraut (German. wiegen 'to weigh') is used to stimulate appetite, improve digestion, regulate weight. Compare: "Wermut ist dank seiner Bitterstoffe in erster Linie appetitanregend und verdauungsfördernd" (Wendelberger, 2013) 'Due to the bitterness content, vermouth primarily causes appetite and promotes digestion'. The men kept a plant decoction of Knabenkraut (German: der Knabe 'guy, young man, boy'; das Kraut 'grass'), orchis, to restore potency. Among the people bearberry is famous for its diuretic effect: leaves of this plant are used for bladder diseases (Annenkov, 1878). The property is reflected in the phytonym Harnkraut (German: der Harn 'urine'). The phytonym Harnkraut is homonymous for the nomination of herniary used to treat urinary tract infection. Another plant for the treatment of diseases of the urinary system is caseweed. The inflammation of kidneys, a bladder and urolithiasis (Volynskii, 1978) was treated with caseweed infusion. Compare: Pinkelkraut (German pinkeln 'urinate'). Hypericum has the folklore name Mannblut (German: der Mann 'husband, man'; das Blut 'blood'), as it is drunk to treat diseases caused by lifting weights. Compare: Mannskraft literally. 'male power'. It is 
widely known that in prolonged cough licorice root has a mucalizing effect, as indicated by the presence of root Husten- (German husten 'cough') in the phytonym Hustenwurzel. The name of the plant is homonymous for soapwort.

4. Phytoonyms containing the name of the diseased organ. The nomination process, in which the name of the diseased organ is included, could proceed on the basis of the external similarity of the separate part of the plant with the diseased organ or symptoms of this disease. In the ancient times, yarrow was already used for radiculitis, pain in the joints and lower back. It was believed that Gliedkraut 'yarrow' (German anatomist. Das Glied 'joint', das Kraut 'herb') helps well with joint diseases. The lungs are the organ most vulnerable to infectious diseases. Among the names of herbs which were used to treat respiratory diseases, in German, it can be noted the lexeme with the root Brust- (German. Die Brust 'chest, sternum, thorax'): Brustwurzel 'angelica'; Brustalant 'elecampane', Lunge (German. Die Lunge anat. 'Lung'): Lungenwurz, Lungenflechte 'lungwort', Lungenklee 'trifolium'; Luft (German. Die Luft 'air'): Luftwurz 'angelica'.

5. Phytoonyms containing the names of the organs of the gastrointestinal tract. If the plant is used to treat diseases of the gastrointestinal tract, the composition of pharmacophitonyms most often reflects such lexemes as the stomach, intestines and liver. For discomfort in the stomach, the Germans especially appreciate the yarrow -Bauchwehkraut (German der Bauch 'belly'; weh 'sick'): "Wegen ihres hohen Gehaltes an Bitterstoffen wird gewöhnliche Schafgarbe vor allet bei Erkrankungen des Magen und Darmes, bei Erkrankungen des Magen und Darmes, bei Erkrankungen des Magen und Darmes, bei Wendelberger E., 2013) "Due to the high bitterness content, yarrow is used for diseases of the stomach and intestines, during bloating"; calamus - Magenwurz (German der Magen 'stomach, belly'): "Man verwendet Kalmus bei Magenkatarrh, Magensenkung" (Wendelberger, 2013). Calamus is used for gastric catarrh and gastric emptying (gastroptosis) '; wormwood - Magenkraut: "Wermut hilft bei Völle-, Druck-, Schmerzgefühl im Magen, lindert Magen- und Darmkrämpfe" (Wendelberger, 2013). "Wormwood helps with feelings of fullness, pressure and pain in the stomach, relieves cramps in the stomach and intestines." Trifolium (Menyánthes) has similar properties, and in German. Magenklee (German der Magen 'stomach'). In the monolingual German directory of medicinal plants, the digestive property of elecampane is recorded: "Neben der auswurffördernden Wirkung wurden verdauungsfördernde, den Gallenfluss anregende Eigenschaften genutzt" (Handbuch, 2011). "With the expectorant effect, digestive and bile-promoting properties have been used." Compare: Darmwurz (German der Darm anat. 'Intestines').

6. Phytoonyms containing the names of the organs of vision. Since antiquity, people have paid great attention to the prevention and treatment of eye diseases. In the "Botanical Dictionary" by N. Annenkov this property of the plant is also noted: "... in folk medicine it is used during eye pain as a lotion ..." (Annenkov, 1878), which was the basis for the formation of the folklore phytonym Augenkraut letterally. 'Eye herb'.In the German handbook (Handbuch, 2012) of medicinal plants it is mentioned the use of raven's eye for the treatment of eye diseases, as the German phytonym Augenkraut evidences letterlly. 'Eye herb'. The German phytonym Augenkraut is homonymous for the celandine nomination. In medicine and cosmetology, valerian (frozen juice) is used to relieve eye inflammation: Augenwurz, Augenwurtzel (German das Auge 'eye').

7. Phytoonyms containing the names of the organs of the cardiovascular system. In the pharmacophitonyms the identification of the names of the cardiovascular system's organs indicates the active practice of treating heart diseases with herbs. For functional disorders of cardiac activity hawthorn infusion is used (Podymov, 1990): Blutdorn (German das Blut 'blood'; der Dorn bot. 'Thorn'); peppermint decoction is also used actively to stimulate heart activity in folk medicine, (Podymov, 1990): Aderminze (German die Ader 'vein, blood vessel, artery'; die Minze 'mint'). Phytoonyms with the root Herz- (German das Herz 'heart') indicate that plants are cardiotonic means :. Herzel, Herzkraut 'shepherd's bag'; Herzgespann, Herzkraut, Herzheil, Herzgold 'motherwort'; Herzkraut, Herztrost, Herzbrot 'lemon balm'.

8. Phytoonyms containing the names of the organs of the female reproductive system. The phytonyms, containing lexemes corresponding to the physiological processes of a woman in the pre-, postand gravidar periods are evidenced about active use of medicinal plants in obstetric and gynecological practice. Nursing mothers were given a Säugekraut broth (German säugen 'to breastfeed') 'yarrow' to increase the amount of milk (Lyskovskii, 2013). Chamomile, called Mutterkraut (German die Mutter 'mother, mother; honey uterus'; das Kraut 'grass'), is used for female diseases (Wendelberger, 2013). The Latin generic name matricaria, derived from the Latin matrix 'womb', should be distinguished separately. The word matrix itself goes back to the noun mater 'mother' (Svetlichnaya, 2003). Compare. also:. Mägdeblume (German die Magd poet 'girl, maiden'; die Blume 'flower'). Ergot is mainly used for uterine bleeding (Svetlichnaya, 2003). In gynecological practice the similar description of the use of the plant is found in German reference books: "Mutterkorn (German die Mutter anat.' Uterus '; das Korn' grain '") ist zum Stillen 
von Gebärmutterblutungen verwendet "(Handbuch, 2011) "Ergot is used to stop uterine bleeding." In case of menstrual irregularities, the lemon balm decoction was used. Compare.also: Frauenkraut literally 'female herb', Frauenwohl literally 'women's well-being', Mutterkraut literally 'mother herb'. In obstetric and gynecological practice Blutgarbe (German das Blut 'blood') 'knotweed' is used as a uterine hemostatic agent. The anti-spasmodic property of valerian was appreciated by herbalists, which was used to alleviate the menopausal suffering of women. Wed: Dammarg (German der Damm anat. 'Crotch'; arg 'evil, bad').

9. Phytoonyms containing the name of the disease which was treated with this plant. Healers gave them "speaking" names in order to determine the main indications for the use of medicinal plants. In the basis the name of the disease was put during which it was recommended to use this plant. In folk medicine, aloe has been used to treat gangrene: Brandbaum (German der Brand honey 'gangrene'). In Germany cat's paw is used cat's paw during diarrhea, Ruhrkrautblume (German die Ruhr 'bloody diarrhea, dysentery') (Wendelberger, 2013). Cornflower is part of the herbal collection for chickenpox: Pockenblume (German die Pocken 'smallpox'). The roots and fresh juice of celandine are used for various neoplasms on the skin, especially for removing warts (Handbuch, 2012): Warzenkraut (German die Warze 'wart'). Datura leaves are dried and smoked for shortness of breath. The monolingual reference book of medicinal plants it is said the following: German. "Daneben wurden Stechapfel-Arten aber auch als Naturarznei eingesetzt, etwa zur Behandlung von Asthma, Keuchhusten oder rheumatischen Beschwerden" (Handbuch, 2012). "Datura varieties are prescribed as natural remedies for asthma, whooping cough, or rheumatic weakness." Compare $\therefore$ German. Asthmakraut (German das Asthma 'asthma'; das Kraut 'grass'). In practice, there is the fact of using Krebsdistel (German der Krebs honey 'Cancer'; die Distel 'thistle') 'tartar' for skin cancer and as a prophylactic agent after tumor removal. The anticonvulsant properties of the decoction and infusion of denotate are reflected in the German phytonym Krampfdistel (German der Krampf 'spasm, spasm'; die Distel bot. 'Thistle'). In the form of a decoction the roots and rhizome of soapwort are used as an expectorant for bronchitis - Hustenwurzel (German husten 'cough', die Wurzel 'root'). In the German herbalists it is recorded: "Früher wurde die Droge häufig bei Katarrhen der Atemwege eingesetzt" (Handbuch, 2011). "Previously, medicinal raw materials were used more often for respiratory tract infections".

\section{CONCLUSION}

Sometimes the external similarity of the morphological part of the plant with a diseased organ or symptoms of a separate disease was sufficient for the use of plants for medicinal purposes. The use of herbs in folk medicine and the process of their nomination were often determined by the real properties of the plant. They were used in folk medicine as the first improvised medicine. For example, hemostatic plants could be used to stop cuts and bleeding during haymaking, so the corresponding lexeme Blut- was included in the nomination process. In diseases of various systems of the human body (reproductive, digestive, cardiovascular, etc.), for the treatment of any pathological processes occurring in the human body, phytonym will always have a lexeme indicating the organ, process or neoplasm that this plant cures, for example, in the treatment of diseases of the digestive system in the names of medicinal plants we find the lexemes Magen-, Darm-; in the treatment of diseases of the respiratory system - Lunge-, etc. Thus, the monolingual approach to the extralinguistic analysis of phytonyms shows that it is the folklore names of medicinal plants that reveal the experience of healing accumulated over centuries.

\section{REFERENCE LIST}

Annenkov, N.A. (1878) Botanical Dictionary. - SPb, 1878. - 646 p.

Bogdanova, N.V., Kolyago, A.L., Fokina, A.A., Sokolova, G.L., Yandakova, E.L. Nominative sentences in languages with different systems (Mari and German). Proceedings of INTCESS 20174th International Conference on Education and Social Sciences 6-8 February,2017-Istanbul, Turkey. Page No. 614617.

Handbuch (2011). Das neue Handbuch der Heilpflanzen. Botanik, Arzneidrogen, Wirkstoffe, Anwendungen. - Stuttgart, 2011. - $504 \mathrm{~S}$.

Handbuch (2012). Das große Handbuch der Kräuter und Heilpflanzen. - Köln, 2012. - 640 S.

Lyskovskii, M.V. (2013) Floral lace. Legends about flowers. - M., 2013. - 319 p.

Podymov, A.I., Suslov, Y.D. (1990) Medicinal plants of the Mari ASSR- Yoshkar-Ola, 1990. - 192 p. 
Rubtcova O.G. (2015) A short four-lingual dictionary of phytonyms (by the material of the Latin, Russian, Mari and German languages). - Yoshkar-Ola, 2015. - 94 p.

Sokolova, G.L., Kolyago, A.L., Fokina, A.A., Rychkov, A.V., Bogdanova, N.V., Trubyanova, I.V., Yandakova, E.L. Expression of purpose in the Mari and the German languages. Proceedings of INTCESS 2017 4th International Conference on Education, Social Sciences and Humanities 10-12 July,2017 - Dubai, U.A.E. P. $240-243$

Svetlichnaya, E.I., Tolok, I.A. (2003) Etymological dictionary of Latin botanical names of medicinal plantsKharkiv, 2003. -288 p.

Volynskii, B. G., Bender, K.I. (1978). Medicinal plants in scientific and folk medicine - Saratov, 1978. - 360 p.

Wendelberger E. (2013) Heilpflanzen. Erkennen. Sammeln. Anwenden. - München, 2013. - 128 S. 